\title{
Hypogonadism after traumatic brain injury
}

\author{
Hipogonadismo após traumatismo craniano encefálico
}

Alexandre Hohl', Tânia Longo Mazzuco², Marisa Helena

César Coral ${ }^{3}$, Marcelo Schwarzbold ${ }^{4}$, Roger Walz ${ }^{4}$

1 Disciplina de Endocrinologia, Hospital Universitário, Universidade Federal de Santa Catarina (UFSC); Núcleo de Pesquisas em Neurologia Experimental e Clínica (Nupnec), UFSC, Florianópolis, SC, Brasil 2 Departamento de Endocrinologia, Centre Hospitalier de I'Université de Montréal (CHUM), Canadá ${ }^{3}$ Disciplina de Endocrinologia Hospital Universitário, UFSC, Florianópolis, SC, Brasil ${ }^{4}$ Nupnec, UFSC

Florianópolis, SC, Brasil
Correspondence to: Alexandre Hohl

Av. Rio Branco, 404/704, torre 1 Centro

88015-200 - Florianópolis, SC, Brasil alexandrehohl@endocrino.org.br

Received on Apr/26/2009

Accepted on Aug/11/2009

\begin{abstract}
Traumatic brain injury (TBI) is the most common cause of death and disability in young adults. Post-TBI neuroendocrine disorders have been increasingly acknowledged in recent years due to their potential contribution to morbidity and, probably, to mortality after trauma. Marked alterations of the hypothalamic-pituitary axis during the post-TBI acute and chronic phases have been reported. Prospective and longitudinal studies have shown that some abnormalities are transitory. On the other hand, there is a high frequency (15\% to $68 \%$ ) of pituitary hormone deficiency among TBI survivors in a long term setting. Post-TBI hypogonadism is a common finding after cranial trauma, and it is predicted to develop in $16 \%$ of the survivors in the long term. Post-TBI hypogonadism has been associated with adverse results in the acute and chronic phases after injury. These data reinforce the need for identification of hormonal deficiencies and their proper treatment, in order to optimize patient recovery, improve their life quality, and avoid the negative consequences of non-treated hypogonadism in the long term. Arq Bras Endocrinol Metab. 2009;53(8):908-14

Keywords

Hypogonadism; brain injuries; testosterone; estradio
\end{abstract}

\section{RESUMO}

O traumatismo cranioencefálico (TCE) é a causa mais comum de morte e incapacidade em adultos jovens. Desordens neuroendócrinas pós-TCE vêm sendo reconhecidas cada vez mais nos últimos anos devido à sua potencial contribuição para a morbidade e, possivelmente, mortalidade após trauma. Alterações acentuadas do eixo hipotálamo-hipófise foram documentadas nas fases aguda e crônica pós-TCE. Estudos prospectivos e longitudinais têm mostrado que algumas anormalidades são transitórias. Por outro lado, existe uma elevada frequência de deficiências hormonais hipofisárias a longo prazo entre os sobreviventes de TCE, que varia de $15 \%$ a $68 \%$. Hipogonadismo pós-TCE é um achado comum a longo prazo e estima-se que, em média, $16 \%$ dos sobreviventes sejam afetados. Hipogonadismo pós-TCE tem sido associado a resultados adversos tanto na fase aguda quanto na fase crônica após a lesão. Esses dados reforçam a necessidade da identificação e adequado tratamento das deficiências hormonais, para otimizar a recuperação do paciente, melhorar a qualidade de vida e evitar as consequências negativas a longo prazo do hipogonadismo não tratado. Arq Bras Endocrinol Metab. 2009;53(8):908-14

Descritores

Hipogonadismo; traumatismos encefálicos; testosterona; estradiol

\section{INTRODUCTION}

$\mathrm{H}$ ypopituitarism was first described by Simmonds (1), in 1914 , as incapacity of the pituitary gland to provide hormones to the body. The first anterior pituitary insufficiency caused by cranial trauma was described in 1918 (2). Hypopituitarism was considered as a rare consequence of traumatic brain injury (TBI) in 1942 , representing $0.7 \%$ of all pituitary insufficiencies (3). However, the diagnosis of post-TBI hypopituitarism became more consistent just in the last decade (4). Nowadays, hypopituitarism is a chronic disease, and medical treatment of this disorder can imitate pituitary 
function. Mortality rises among patients suffering from hypopituitarism (5).

\section{HEAD AND BRAIN INJURIES: A PUBLIC HEALTH PROBLEM}

TBI refers to the significant potential for brain parenchyma lesion after cranial trauma (6). TBI is usually classified with the Glasgow Coma Scale (GCS) (7) as severe (GCS $\leq 8)$, moderate (GCS $=9-13$ ) and mild $(\mathrm{GCS}=14-15)$. Severe TBI and moderate TBI each represent about $10 \%$ of all cases, while the remaining $80 \%$ of the cases are classified as mild (8).

TBI is one of the main causes of death and disability in industrialized and developing countries, causing physical, cognitive, behavioral, psychiatric and social damages (9). There are four main causes of TBI: traffic accidents, accidents at work, sports accidents, and violence (10-12).

TBI incidence has increased in the last decades. It has been estimated that about 180 to 250 out of 100,000 people in industrialized countries die or are admitted to the hospital every year because of TBI (13). It is the main cause for death and disability among young adults (14), and survivors usually experience physical and psychological after effects (15).

TBI epidemiology has been studied for several years in many countries. Because of the different inclusion criteria of each study, a valid indicator of TBI incidence may be the hospital admission rate due to TBI. The rates varied from 91 per 100,000 patients in Spain (16) to more than 300 per 100,000 admissions in Italy (17), South Africa (18), Australia (19) and Scotland (20). In 1999 , there were 230,000 admissions due to TBI in the United States. Since 1998, 1.5 to 2 million TBI patients have been reported yearly, and more than 50,000 died $(25,000$ of them as a direct consequence of their trauma) (21). It is estimated that five million people in the United States suffer nowadays TBI consequences (22).

According to a study on hospital morbid-mortality in the city of São Paulo (SP), in 1997, based on the Hospital Information System of the Brazilian Single Health System (SIH-SUS), 29,717 patients were admitted due to accidents and poisoning. Among these, 3,635 patients ( $12 \%$ ) had TBI as main diagnosis; admission rate was $0.36 / 1,000$ inhabitants and hospital mortality was $10 \%(23)$. Other Brazilian cities presented similar results (24). In the extended metropolitan area of the city of Florianópolis (SC), 75\% of severe TBI cases were related to traffic accidents (25).

\section{PITUITARY ANATOMY AND LESION MECHANISMS IN TRAUMATIC BRAIN INJURY}

It is well known that the pituitary gland and the hypothalamus make up a unit that controls the function of several endocrine glands. In the hypothalamo-pituitary axis, nervous and endocrine gland cells, involved in cellto-cell communication, share certain characteristics, such as secretion of chemical messengers (neurotransmitters or hormones) and electric activity. A simple chemical messenger (peptide or amine) can be produced by the neurons as a neurotransmitter or a neurohormone and by the endocrine, as a classic hormone (26).

The pituitary gland is divided into adenobypophysis (anterior portion) and neurohypophysis (posterior portion). It is located in the sella turcica, where it is lined superiorly by a dense coat of connective tissue - the sellar diaphragm (26). The pituitary gland is vascularized by branches of the internal carotid artery. These vessels constitute a capillary plexus in the median eminence of the hypothalamus. The blood in this area reaches the anterior pituitary gland through the portal veins of the pituitary stalk. The medium and inferior hypophysial arteries supply the pituitary stalk and the posterior pituitary with arterial blood. However, the anterior pituitary is not included in this supply of arterial blood; it is supplied with oxygenated blood through the internal and external plexus of the median eminence (27).

The pathophysiology of post-TBI hypopituitarism has not been completely elucidated yet, but pituitary anatomy and its blood supply are involved in this process. Autopsy results of those individuals who survived for 12 hours after TBI show that $35 \%$ of them had strokes that covered approximately $70 \%$ of the anterior pituitary, in the peripheral region, where the blood supply is carried out by the pituitary portal veins (28).

\section{CLINICAL AND LABORATORY CHARACTERISTICS OF HYPOGONADISM}

Hypopituitarism can be a subclinical condition, identified only by hormonal tests, or its clinical manifestations can be acute and severe, pointing toward the need for immediate treatment. However, the deficit of gonadotropins will lead to partial hypopituitarism due to hypogonadotropic hypogonadism presenting chronic morbidity. Hypogonadism in men is associated with decrease in life quality, fatigue, mood impairment, insomnia, osteoporosis, loss of libido, impaired sexual function, loss of facial, pubic and body hair. In other hand, hypogonadism in women is 
associated with loss of libido, dyspareunia, oligoamenorrhea, infertility and decreased quality of life (29).

In principle, the combination of low blood levels of peripheral hormones and inadequately low levels of pituitary hormones (below the upper limit of the reference range) indicates hypopituitarism (30). Table 1 provides a summary of the attempts to evaluate the gonadotropic function.

Table 1. Criteria for hormone deficiency of the gonadotropic axis

\begin{tabular}{ll}
\hline Women & \\
\hline Clinical/laboratory & $\begin{array}{l}\text { Oligoamenorrhea, estradiol }<30 \mathrm{pg} / \mathrm{mL}, \text { LH and FSH } \\
\text { inadequately low }\end{array}$ \\
\hline Men & \\
\hline Testosterone & Low $(<300 \mathrm{ng} / \mathrm{dL}), \mathrm{LH}$ and FSH inadequately low
\end{tabular}

LH: luteinizing hormone; FSH: follicle-stimulating hormone.

\section{NEUROENDOCRINE DYSFUNCTION AFTER BRAIN AND HEAD INJURIES}

Hypopituitarism can be complete (panhypopituitarism) or partial (isolated deficiency or multiple deficiencies), and also temporary or permanent. Its clinical manifestations may vary from mild to moderate and to severe, depending on the number of pituitary hormones affected, rate of appearance and patient age. Mild hypopituitarism can remain undetected for years. The diagnosis of complete deficiency demands basal hormonal dosage, while dynamic endocrine tests are usually necessary for detecting partial deficiencies. Absence of lesion during nuclear magnetic resonance (NMR) or computed tomography (CT) does not exclude a pituitary defect (31).

The patterns of post-TBI endocrine abnormalities vary if the lesion is located in the hypothalamus, in the anterior or posterior pituitary, or in the superior or inferior portion of the pituitary stalk. Most severe accidents damage not only structures but endocrine production as well (32). Incidence and prevalence of post-TBI neuroendocrine dysfunction is high, according to the latest studies. At least one neuroendocrine dysfunction was found in $35 \%$ to $50 \%$ of individuals with TBI (33-35). Diagnosis is reached by the appearance of low pituita- ry hormone levels and by dynamic endocrine tests that show low pituitary reserves.

\section{Acute phase}

A series of studies has evaluated the acute neuroendocrine alterations following TBI. Former studies were not specifically designed to evaluate hypopituitarism frequency during the acute post-TBI phase, but simply tried to correlate the neuroendocrine changes to the severity of the cranial trauma (36-38). More recently, much attention has been given to determining the frequency of hormonal deficiencies in cohorts of patients with TBI (39-4l). Design, methodologies and results of theses studies are summarized in table 2 .

Nowadays, the studies do not present a consensus about acute post-TBI endocrine alterations. These variations may reflect differences in patient selection process, severity of the injuries, study design, methodology and calendar for evaluations. A research by Cernack and cols. (42) showed that blood testosterone is related to injury severity. However, these findings were not supported by Lee and cols. (43).

Some of the changes in the acute phase, especially hypogonadism and hyperprolactinemia, are not specific for TBI and may reflect adaptive responses to accidents and to serious diseases with uncertain clinical results.

\section{Chronic phase}

Anterior pituitary dysfunction following TBI has been widely studied in recent years. Twelve systematic studies are summarized in table 3 .

The study by Kelly and cols. (33) presents a bias in its results, since all patients with pituitary dysfunction had experienced hypoxic and hypotensive insults during the TBI episode. Agha and cols. (44) evaluated 102 patients with moderate or severe TBI 17 months (median) after the trauma. In order to ensure a meticulous evaluation of the somatotropic and gonadotropic axes, each patient was submitted to two separate stimulation tests. At least $28 \%$ of the patients had one hormonal abnormality, and $11.8 \%$ had hypogonadism.

Table 2. Pattern of hypogonadism in acute traumatic brain injury

\begin{tabular}{|c|c|c|c|c|c|}
\hline \multirow{2}{*}{ Study } & \multirow{2}{*}{ Number of patients } & \multirow{2}{*}{ Time to testing } & \multirow{2}{*}{ GCS score } & \multicolumn{2}{|c|}{ Neuroendocrine axis assessed } \\
\hline & & & & Gonadal & Prolactin \\
\hline Cernak and cols. (42) & 31 & 7 days & $13-15$ & $\downarrow$ Testosterone & $\mathrm{N} / \mathrm{A}$ \\
\hline Agha and cols. (39) & 50 & 12 days median & $3-13$ & $80.0 \%$ deficient & $52 \%$ high \\
\hline Tanriverdi and cols. (41) & 52 & 24 hours & $3-15$ & $41.6 \%$ deficient & $12 \%$ high \\
\hline
\end{tabular}

GCS: Glasgow Coma Scale; N/A: not available. 


\begin{tabular}{|c|c|c|c|c|}
\hline Study & Number of patients & GCS score & $\begin{array}{l}\text { Time to testing } \\
\text { (months) }\end{array}$ & $\begin{array}{l}\text { Gonadotropin } \\
\text { deficiency (\%) }\end{array}$ \\
\hline Kelly and cols. (33) & 22 & $3-15$ & Median 26 & 22.7 \\
\hline Lieberman and cols. (34) & 70 & N/A & Median 13 & 1.4 \\
\hline Agha and cols. (45) & 102 & $3-13$ & Median 17 & 11.8 \\
\hline Aimaretti and cols. (35) & 100 & $3-15$ & 3 & 17.0 \\
\hline Bondanelli and cols. (46) & 50 & $3-15$ & Range 12-64 & 14.0 \\
\hline Popovic and cols. (47) & 67 & $9-13$ & Median 44 & 9.0 \\
\hline Leal-Cerro and cols. (48) & 99 & $<8$ & $>12$ & 17.0 \\
\hline Aimaretti and cols. (49) & 70 & $3-15$ & 12 & 11.4 \\
\hline \multirow[t]{2}{*}{ Schneider and cols. (50) } & 78 & $3-15$ & 3 & 32.0 \\
\hline & & & 12 & 20.0 \\
\hline Tanriverdi and cols. (41) & 52 & $3-15$ & 12 & 7.7 \\
\hline Herrmann and cols. (51) & 76 & $<8$ & Range 5-47 & 17.0 \\
\hline Klose and cols. (52) & 104 & $3-15$ & Median 13 & 2.0 \\
\hline
\end{tabular}

GCS: Glasgow Coma Scale; N/A: not available.

A research by Bondanelli and cols. (46) was one of the few studies that related a lower score in the GCS to the presence of post-TBI hypopituitarism. Additionally, Klose and cols. (52) observed a relationship between post-TBI hypopituitarism and severe cranial traumas, rise of the intracranial pressure (ICP) and longer endotracheal intubation time. Although these studies present varied results, there is consensus that post-TBI hypogonadism is a common finding after cranial trauma, and it is prognosticated for $16 \%$ of the survivors in long term setting (29).

\section{PITUITARY EVALUATION: WHO AND WHEN?}

Considering the high number of post-TBI pituitary deficiencies, the ideal approach would be the test of any patient with a relevant cranial trauma. Obviously, this is not feasible, due to the huge number of TBI cases all over the world. Arbitrarily, the evaluation strategy in several research centers has excluded those patients who are in a very severe condition or those with mild or irrelevant traumas.

Therefore, most clinical researchers are not studying patients with very severe post-TBI deficiencies - in other words, patients in a vegetative state or without autonomous activity. The reasoning for excluding this specific group of patients is that there are no available data showing that diagnosis and pituitary hormone replacement will bring any benefit to patients in such extreme conditions. It is evident that this policy may change in the future, when more information will be available. There is an even greater controversy about the decision of not testing patients with mild TBI, since there are already reports showing that minor cranial traumas without loss of consciousness or late neurological deficiencies can also be associated with severe hypopituitarism $(4,53)$. Nowadays, there are signs showing that a substantial number of patients with previous diagnosis of idiopathic hypopituitarism had a previous history of mild TBI, which explains late diagnosis when compared to any other cause of hypopituitarism (54).

Although most post-TBI hypogonadism cases are related to severe traumas, several studies were not able to correlate a lower GCS score to hypogonadism (33). Based on this information, Lorenzo and cols. (55) suggest the following criteria for selecting the ideal TBI patients to be tested:

- patients with initial GCS of 13 or less or with GCS between 13 and 15 with abnormalities on brain images;

- patients who should remain under observation for at least 24 hours;

- patients with intracranial hemorrhagic lesions;

- patients who develop acute hypogonadism manifestations immediately after TBI;

- patients with current hypogonadism signs or symptoms.

Patients with severe dysautonomia or in vegetative state, until further studies are carried out, were excluded. 
The time factor is particularly important in postTBI hypogonadism. The development or disappearance of post-TBI sequels does not have a specific time to occur. Temporary and mild hypogonadism can disappear after several months, since the damaged tissues can recover spontaneously. According to current evidences and considering the huge amount of potential post-TBI patients to be tested for hypogonadism (and hypopituitarism) all over the world, it seems to be reasonable that follow-up be done at least one year after the TBI event and not before this period of time $(33,37,38)$.

Again, Lorenzo and cols. (55) suggest the time for testing the aforementioned TBI patients:

- based on evidence:

- adults: one year after the trauma.

- according to experimental protocols:

- during the peritraumatic period (before patient is discharged from the hospital);

- three months after the trauma;

- a long time after the trauma (five years or more).

\section{MORBIDITY IN BRAIN AND HEAD INJURIES AND HORMONAL REPLACEMENT}

Recent advances in neurosurgery and in intensive therapy resulted in increased survival rates in moderate and severe TBI patients. This also led to an increasingly higher number of post-TBI patients with neurological, cognitive, psychological, behavioral and social problems.

Rehabilitation plays an important role in reducing the impact caused by TBI, since it restores the impaired functions or counterbalances lost functions. For postTBI patients, the main goal of rehabilitation is to provide them with maximal functional independence and improved quality of life (13).

Some abnormalities identified in different studies about pituitary function in post-TBI patients are partial, and their clinical meaning can be uncertain when compared to healthy individuals. However, they may have great relevance to TBI patients with physical and neuropsychiatric sequels, which cause increased morbidity and are detrimental to their recovery.

Testosterone deficiency in males is associated with the reduction of lean mass, muscle weakness and adynamia $(56,57)$. Male or female hypogonadism may evolve, reduce mineral bone density and cause osteoporosis (58). This scenario may be aggravated by post-TBI immobility, as well as by the coexistence of other pituitary deficiencies.
Therefore, the failure in identifying the hormone deficit and treating it may have deleterious consequences for TBI patients and may be detrimental to their recovery and rehabilitation, and increase morbidity. Klose and cols. (52) studied 104 TBI patients, whose post-traumatic hypopituitarism was independently associated with a worse quality of life, abnormal body composition and adverse metabolic profile, evidencing the clinical importance of this condition, as well as its relevance to Public Health.

Presently, there are no prospective studies either on acute or chronic phases that may provide a prognosis for post-TBI patients, considering the pituitary hormone profile. Similarly, no prospective study has yet been able to determine the variables associated with the development of hypopituitarism, in either post-TBI acute phase or chronic phase. Our group evaluated 748 patients with history of severe TBI. Eighty-four percent $(\mathrm{n}=631)$ of patients were male. The mean age of patients was $34.8( \pm 16.3)$ years and the overall mortality was $33.3 \%$. The causes of TBI were road accident (30.1\%), automobile accident $(23 \%)$, fall $(12.8 \%)$, motorcycle accident $(24.3 \%)$, aggression $(3.7 \%)$, bicycle accident $(3.2 \%)$, others $(2.8 \%)$. Our study noticed that age, cranial computed tomography findings, GCS, pupil examination and presence of thoracic trauma at patients' admission were independently associated with mortality (25). It is possible that pituitary hormonal disturbances in the acute and chronic phases will contribute to these findings, indicating the need for further studies. Currently, our group is conducting a prospective study to assess the pituitary function of patients with severe TBI in the first 72 hours. The same patients will be reassessed after one year.

\section{CONCLUSION}

TBI is a critical Public Health problem associated with high morbidity, mainly among the economically active population. Moreover, it results in high costs for the individual and the society in general. Many studies demonstrate that post-TBI hypopituitarism is relatively common and that it may contribute to morbidity associated with cranial trauma. However, for most patients, these deficiencies fail to be identified or treated. Considering the high incidence of TBI, post-TBI hypogonadism arises as a critical problem for Public Health, due to the unproductive condition of non-treated patients, as well as to comorbidities brought about by metabolic 
alterations. Hormonal replacement therapy may reduce morbidity, optimize rehabilitation and improve the quality of life of the patients. Follow-up programs for post-traumatic hypopituitarism should constitute a part of the clinical routine care for patients with cranial trauma. These programs require multidisciplinary cooperation among endocrinologists, neurosurgeons, psychologists and other Health professionals in order to help cranial trauma victims to resume their normal life.

Acknowledgements: this work was supported by National Counsel of Technological and Scientific Development (CNPq) and Fundação de Apoio à Pesquisa Científica e Tecnológica de Santa Catarina (Fapesc).

Disclosure: no potential conflict of interest relevant to this article was reported.

\section{REFERENCES}

1. Simmonds M. Ueber hypophysisschwund mit tödlichem Ausgang. Dtsch Med Wochenschr. 1914;40(7):322-3.

2. Cyran E. Hypophysenschädigung durch Schädelbasisfraktur. Dtsch Med Wochenschr. 1918;44(45):1261.

3. Escamilla RF, Lisser, H. Simmonds disease. J Clin Endocrinol. 1942;2(2):65-96.

4. Benvenga S, Campenní A, Ruggeri RM, Trimarchi F. Clinical review 113: Hypopituitarism secondary to head trauma. J Clin Endocrinol Metab. 2000;85(4):1353-61.

5. Tomlinson JW, Holden N, Hills RK, Wheatley K, Clayton RN, Bates AS, et al. Association between premature mortality and hypopituitarism. West Midlands Prospective Hypopituitary Study Group. Lancet. 2001;357(9254):425-31.

6. Heegaard W, Biros M. Traumatic brain injury. Emerg Med Clin North Am. 2007;25(3):655-78, viii.

7. Teasdale G, Jennett B. Assessment of coma and impaired consciousness. A practical scale. Lancet. 1974;2(7872):81-4.

8. Tagliaferri F, Compagnone C, Korsic M, Servadei F, Kraus J. A systematic review of brain injury epidemiology in Europe. Acta Neurochir (Wien). 2006;148(3):255-68; discussion 68.

9. Schwarzbold M, Diaz A, Martins ET, Rufino A, Amante LN, Thais $\mathrm{ME}$, et al. Psychiatric disorders and traumatic brain injury. Neuropsychiatr Dis Treat. 2008;4(4):797-816.

10. Gururaj G. The effect of alcohol on incidence, pattern, severity and outcome from traumatic brain injury. J Indian Med Assoc. 2004;102(3):157-60, 63.

11. de Bruijn SF, Keunen RW. [Brain injury in boxers and soccer players; an advisory report from the National Health Council of the Netherlands]. NedTijdschr Geneeskd. 2004;148(45):2209-12.

12. León-Carrión J, Ramos FJ. Blows to the head during development can predispose to violent criminal behaviour: rehabilitation of consequences of head injury is a measure for crime prevention. Brain Inj. 2003;17(3):207-16.

13. Mazaux JM, Richer E. Rehabilitation after traumatic brain injury in adults. Disabil Rehabil. 1998;20(12):435-47.

14. KalsbeekWD, McLaurin RL, Harris BS 3rd, Miller JD. The National Head and Spinal Cord Injury Survey: major findings. J Neurosurg. 1980;Suppl:S19-31.

15. van Baalen B, Odding E, Maas Al, Ribbers GM, Bergen MP, Stam HJ. Traumatic brain injury: classification of initial seve- rity and determination of functional outcome. Disabil Rehabil. 2003;25(1):9-18.

16. Vázquez-Barquero A, Vázquez-Barquero JL, Austin $\mathrm{O}$, Pascual J, Gaite $\mathrm{L}$, et al. The epidemiology of head injury in Cantabria. Eur $\mathrm{J}$ Epidemiol. 1992;8(6):832-7.

17. Servadei F, Verlicchi A, Soldano F, Zanotti B, Piffer S. Descriptive epidemiology of head injury in Romagna and Trentino. Comparison between two geographically different Italian regions. Neuroepidemiology. 2002;21(6):297-304.

18. Nell V, Brown DS. Epidemiology of traumatic brain injury in Johannesburg--II. Morbidity, mortality and etiology. Soc Sci Med. 1991;33(3):289-96.

19. Hillier SL, Hiller JE, Metzer J. Epidemiology of traumatic brain injury in South Australia. Brain Inj. 1997;11(9):649-59.

20. Jennett B, MacMillan R. Epidemiology of head injury. Br Med J (Clin Res Ed). 1981;282(6258):101-4.

21. Thurman DJ, Alverson C, Dunn KA, Guerrero J, Sniezek JE. Traumatic brain injury in the United States: A public health perspective. J HeadTrauma Rehabil. 1999;14(6):602-15.

22. Masel BE. Rehabilitation and hypopituitarism after traumatic brain injury. Growth Horm IGF Res. 2004;14 Suppl A:S108-13.

23. Koizumi MS, Lebrão ML, Mello-Jorge MH, Primerano V. [Morbidity and mortality due to traumatic brain injury in Sao Paulo City, Brazil, 1997]. Arq Neuropsiquiatr. 2000;58(1):81-9.

24. Rodrigues TP, Dias MA, Hohl A, Mazzuco TL. Pathophysiology of the traumatic brain injury and post-traumatic hypopituitarism. Revista Biosaúde. 2008;10(2):129-46.

25. Martins ET, Linhares MN, Sousa DS, Schroeder HK, Meinerz J, Rigo LA, et al. Mortality in severe traumatic brain injury: a multivariated analysis of 748 Brazilian patients from Florianopolis City. JTrauma. 2009;67(1):85-90.

26. Sam S, Frohman LA. Normal physiology of hypothalamic pituitary regulation. Endocrinol Metab Clin North Am. 2008;37(1):1-22, vii.

27. Reichlin $\mathrm{S}$. Neuroendocrinology of the pituitary gland. Toxicol $\mathrm{Pa}$ thol. 1989;17(2):250-5.

28. Kornblum RN, Fisher RS. Pituitary lesions in craniocerebral injuries. Arch Pathol. 1969;88(3):242-8.

29. Agha A, Thompson CJ. High risk of hypogonadism after traumatic brain injury: clinical implications. Pituitary. 2005;8(3-4):245-9.

30. Clapauch R, Carmo AM, Marinheiro L, Buksman S, Pessoa I. Laboratory diagnosis of late-onset male hypogonadism andropause. Arq Bras Endocrinol Metabol. 2008;52(9):1430-8.

31. Popovic V, Aimaretti G, Casanueva FF, Ghigo E. Hypopituitarism following traumatic brain injury. Front Horm Res. 2005;33:33-44.

32. Yuan $X Q$, Wade CE. Neuroendocrine abnormalities in patients with traumatic brain injury. Front Neuroendocrinol. 1991;12(3):209-30.

33. Kelly DF, Gonzalo IT, Cohan P, Berman N, Swerdloff R, Wang C. Hypopituitarism following traumatic brain injury and aneurysmal subarachnoid hemorrhage: a preliminary report. J Neurosurg. 2000;93(5):743-52.

34. Lieberman SA, Oberoi AL, Gilkison CR, Masel BE, Urban RJ. Prevalence of neuroendocrine dysfunction in patients recovering from traumatic brain injury. J Clin Endocrinol Metab. 2001;86(6):2752-6.

35. Aimaretti G, Ambrosio MR, Di Somma C, Fusco A, Cannavò S, Gasperi $M$, et al. Traumatic brain injury and subarachnoid haemorrhage are conditions at high risk for hypopituitarism: screening study at 3 months after the brain injury. Clin Endocrinol (Oxf). 2004;61(3):320-6.

36. Feibel J, Kelly M, Lee L, Woolf P. Loss of adrenocortical suppression after acute brain injury: role of increased intracranial pressure and brain stem function. J Clin Endocrinol Metab. 1983;57(6):1245-50.

37. Hackl JM, Gottardis M, Wieser C, Rumpl E, Stadler C, Schwarz S, et al. Endocrine abnormalities in severe traumatic brain injury--a 
cue to prognosis in severe craniocerebral trauma? Intensive Care Med. 1991;17(1):25-9.

38. Della Corte F, Mancini A, Valle D, Gallizzi F, Carducci P, Mignani V, et al. Provocative hypothalamopituitary axis tests in severe head injury: correlations with severity and prognosis. Crit Care Med. 1998;26(8):1419-26.

39. Agha A, Rogers B, Mylotte D, Taleb F, Tormey W, Phillips J, et al. Neuroendocrine dysfunction in the acute phase of traumatic brain injury. Clin Endocrinol (Oxf). 2004;60(5):584-91.

40. Cohan P, Wang C, McArthur DL, Cook SW, Dusick JR, Armin B, et al. Acute secondary adrenal insufficiency after traumatic brain injury: a prospective study. Crit Care Med. 2005;33(10):2358-66.

41. Tanriverdi F, Senyurek H, Unluhizarci K, Selcuklu A, Casanueva FF, Kelestimur F. High risk of hypopituitarism after traumatic brain injury: a prospective investigation of anterior pituitary function in the acute phase and 12 months after trauma. J Clin Endocrinol Metab. 2006;91(6):2105-11.

42. Cernak I, Savic VJ, Lazarov A, Joksimovic M, Markovic S. Neuroendocrine responses following graded traumatic brain injury in male adults. Brain Inj. 1999;13(12):1005-15.

43. Lee SC, Zasler ND, Kreutzer JS. Male pituitary-gonadal dysfunction following severe traumatic brain injury. Brain Inj. 1994;8(6):571-7.

44. Agha A, Rogers B, Sherlock M, O'Kelly P, Tormey W, Phillips J, et al. Anterior pituitary dysfunction in survivors of traumatic brain injury. J Clin Endocrinol Metab. 2004;89(10):4929-36.

45. Agha A, Thornton E, O'Kelly P,Tormey W, Phillips J,Thompson CJ. Posterior pituitary dysfunction after traumatic brain injury. J Clin Endocrinol Metab. 2004;89(12):5987-92.

46. Bondanelli M, De Marinis L, Ambrosio MR, Monesi M, Valle D, Zatelli MC, et al. Occurrence of pituitary dysfunction following traumatic brain injury. J Neurotrauma. 2004;21(6):685-96.

47. Popovic V, Pekic S, Pavlovic D, Maric N, Jasovic-Gasic M, Djurovic $B$, et al. Hypopituitarism as a consequence of traumatic brain injury (TBI) and its possible relation with cognitive disabilities and mental distress. J Endocrinol Invest. 2004;27(11):1048-54.

48. Leal-Cerro A, Flores JM, Rincon M, Murillo F, Pujol M, Garcia-Pesquera $F$, et al. Prevalence of hypopituitarism and growth hormone deficiency in adults long-term after severe traumatic brain injury. Clin Endocrinol (Oxf). 2005;62(5):525-32.

49. Aimaretti G, Ambrosio MR, Di Somma C, Gasperi M, Cannavo S, Scaroni C, et al. Residual pituitary function after brain injuryinduced hypopituitarism: a prospective 12-month study. J Clin Endocrinol Metab. 2005;90(11):6085-92.

50. Schneider HJ, Schneider M, Saller B, Petersenn S, Uhr M, Husemann $B$, et al. Prevalence of anterior pituitary insufficiency 3 and 12 months after traumatic brain injury. Eur $\mathrm{J}$ Endocrinol. 2006;154(2):259-65.

51. Herrmann BL, Rehder J, Kahlke S, Wiedemayer H, Doerfler A, Ischebeck W, et al. Hypopituitarism following severe traumatic brain injury. Exp Clin Endocrinol Diabetes. 2006;114(6):316-21.

52. Klose M, Juul A, Poulsgaard L, Kosteljanetz M, Brennum J, FeldtRasmussen U. Prevalence and predictive factors of post-traumatic hypopituitarism. Clin Endocrinol (Oxf). 2007;67(2):193-201.

53. Yamanaka C, Momoi T, Fujisawa I, Kikuchi K, Kaji M, Sasaki H, et al. Acquired growth hormone deficiency due to pituitary stalk transection after head trauma in childhood. Eur J Pediatr. 1993;152(2):99-101.

54. Casanueva FF, Leal A, Koltowska-Häggström M, Jonsson P, Góth MI.Traumatic brain injury as a relevant cause of growth hormone deficiency in adults: A KIMS-based study. Arch Phys Med Rehabil. 2005;86(3):463-8.

55. Lorenzo M, Peino R, Castro Al, Lage M, Popovic V, Dieguez C, et al. Hypopituitarism and growth hormone deficiency in adult subjects after traumatic brain injury: who and when to test. Pituitary. 2005;8(3-4):233-7.

56. Bhasin S, Cunningham GR, Hayes FJ, Matsumoto AM, Snyder PJ, Swerdloff RS, et al.Testosterone therapy in adult men with androgen deficiency syndromes: an endocrine society clinical practice guideline. J Clin Endocrinol Metab. 2006;91(6):1995-2010.

57. Wu FC, von Eckardstein A. Androgens and coronary artery disease. Endocr Rev. 2003;24(2):183-217.

58. Clapauch R, Braga DJ, Marinheiro LP, Buksman S, SchrankY. Risk of late-onset hypogonadism (andropause) in Brazilian men over 50 years of age with osteoporosis: usefulness of screening questionnaires. Arq Bras Endocrinol Metabol. 2008;52(9):1439-47. 